\title{
Entrenching Decentralisation in Africa: A Review of the African Charter on the Values and Principles of Decentralisation, Local Governance and Local Development
}

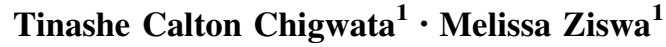

Published online: 27 February 2018

(C) T.M.C. Asser Press 2018

\begin{abstract}
The African Union (AU) adopted the African Charter on the Values and Principles of Decentralisation, Local Governance and Local Development (African Charter on Decentralisation) in 2014. The Charter seeks to promote decentralisation as a vehicle for improving the livelihood of people on the African continent. It is the first to provide a decentralisation framework or model framework for local government for the African continent. Like most international instruments, member states of the AU will only be legally bound by the Charter once they have ratified it. Most Member States of the AU have not ratified the Charter due to varying reasons, including, the fact that the ratification process in many countries is often cumbersome. Non-ratification could also be due to the fact that there is not yet a clear understanding of the meaning and significance of the decentralisation framework which the Charter provides. Thus, the actual impact of the Charter on changing the poor state of local government on the African continent upon coming into operation is as yet unknown. This problem is inflated by the fact that there is present no scholarly commentary on the Charter, given that it is relatively new. This article provides a critical analysis of the Charter, looking at its strengths and weakness, against the background of the international literature on decentralisation and 'best' practices on local government.
\end{abstract}

Keywords African Union - African Charter on the Values, and Principles of Decentralisation, Local Governance and Local Development · Analysis · Local autonomy

Tinashe Calton Chigwata

tchigwata@gmail.com

1 University of the Western Cape, Cape Town, South Africa 


\section{Introduction}

The African Union (AU) adopted the African Charter on the Values and Principle of Decentralisation, Local Governance and Local Development (African Charter on Decentralisation) in 2014. The African Charter on Decentralisation was inspired by the Yaounde Declaration of 2005 which was adopted by the African Ministers in charge of Decentralisation and Local Development in their respective countries. The Yaounde Declaration stresses the importance of a participatory democracy where local communities, groups and organisations can deliberate on their own needs, develop their own programmes for change, and influence policy processes to respond to those needs. ${ }^{1}$ The African Charter on Decentralisation succeeded the African Charter for Popular Participation in Development and Transformation ${ }^{2}$ and the African Charter on Democracy, Elections and Governance (the African Charter on Democracy). What the African Charter on Decentralisation has in common with these charters is that they all strive to promote and strengthen good governance through the institutionalisation of transparency, accountability and participatory democracy. For instance, the African Charter on Democracy adopted in 2007 recognised the need for member countries of the $\mathrm{AU}$ to decentralise power to democratically elected local authorities. ${ }^{3}$ However, it did not stipulate how decentralisation was to be embarked upon and what shape it would take. The African Charter on Decentralisation adopted 14 years later is not only the first to require decentralisation but also to provide a framework to shape such decentralisation.

The objective of the African Charter on Decentralisation, as provided for in its preamble, is to 'promote the values and principles of decentralisation, local governance and local development in Africa as a means for improving the livelihood of all the people on the African continent'. It provides a decentralisation framework or model for local government which member countries should adhere to when drafting and implementing laws and regulations which relate to decentralisation in their respective countries. The decentralisation framework covers a range of aspects, from powers and functions of local government to the fiscal aspects, as well as supervision and co-operation measures. Like most international instruments, Member States of the AU will only be legally bound by the Charter once they have ratified it.

The African Charter on Decentralisation is relatively new having been adopted only in 2014. As of 08 February 2018; only Burundi, Madagascar and Namibia had ratified the Charter. ${ }^{4}$ The slow pace of ratification can largely be attributed to the ratification process in many countries which is often cumbersome. It could also be due to the fact that there is not yet a clear understanding of the meaning and significance of the decentralisation framework provided by the Charter. The ratification of the Charter may mean that the relevant national governments will

\footnotetext{
1 Preamble, Yaounde Declaration of 29 October 2005.

2 African Charter for Popular Participation in Development and Transformation, 1990.

3 Article 34 African Charter on Democracy.

4 See African Union (2018)
} 
have to relinquish some of their powers, authority and resources to local government which they might not be willing or prepared to do. Countries such as South African, Uganda and Kenya, have perhaps far developed constitutional frameworks for decentralisation than provided by the Charter. ${ }^{5}$ Thus, there may be little motivation in these countries to ratify a treaty that may not bring any tangible benefits.

Most local governments on the African continent are ineffective, characterised by poor political accountability of local authorities, poor service delivery as well as unresponsiveness to local needs. ${ }^{6}$ The key question thus is: will the African Charter on Decentralisation materially change local governance on the African continent for the better? This question is significant given that the content of the Charter and its eventual implementation will determine whether its objective of improving the wellbeing of the people on the African continent will be realised. If the decentralisation framework enshrined in the Charter is effective and its values and principles are fully implemented, then there is greater potential for improving the state of local governments in African countries. Conversely, the ratification and implementation by member countries of a Charter that provides a weak decentralisation framework may lead to the entrenchment of service delivery and developmental challenges currently being experienced on the continent. Such challenges include the deepening of poverty, and the quantity and quality of public services that are below expected standards. Thus, an understanding of the Charter, its strength and weakness, in light of the objectives it seeks to realise, is important and is the focus of this article.

The African Charter on Decentralisation defines decentralisation loosely as the transfer of power, responsibilities, capacities and resources from national to subnational entities of government with the aim of strengthening the ability of the latter to both foster people's participation and the delivery of quality services. ${ }^{7}$ Local governments are the most common subnational entities on the African continent and tend to have significant responsibilities over the provisions of basic public services. The decentralisation of powers, responsibilities and resources to these lower governments can enhance service delivery, promote development, deepen democracy, and engender peace. International literature suggests, however, that only appropriately designed decentralisation programmes have the potential to realise those goals. ${ }^{8}$ It emphasises that when designing a decentralisation programme it is important to take into account the different contexts and environments that exist within and beyond countries. Further, the institutional design of a developmental system of local government should protect its existence and provide democratic governance at the local level. Furthermore, local government should be assigned significant and relevant powers, including revenue

\footnotetext{
5 The same argument can be raised with respect to Zimbabwe and Zambia, which have recognised local government and the requirement for devolution in their respective constitutions in 2013 and 2016, respectively.

${ }^{6}$ Bratton (2012), p. 516.

7 Article 1 African Charter on Decentralisation.

8 See De Visser (2005), p. 63; Hatchard et al. (2004), p. 9; Litvack and Seddon (1999), p. 6.
} 
generating and expenditure powers. The design should also empower the national government to supervise the local government while providing for mechanisms fostering co-operation among governments. Thus, an evaluation of the African Charter on Decentralisation is undertaken against the background of these key design features for a developmental local government drawn from the international literature on decentralisation and 'best' practices on local government. The article is also organised along these features.

\section{Defining Decentralisation Within the African Context}

A decentralisation programme should be tailored to meet the particular local environment given the differences in geography, demography, levels of disparity, and local customs, as well as the disparities within and between countries, especially on the African continent. Thus, a one-size-fits-all approach is strongly discouraged, given the acute rural-urban divide in most parts of Africa owing to aspects, such as, colonialism and apartheid. The result is that urban and rural areas have unequal resource raising potential due to the different levels of economic development. In most parts of Africa, rural areas continue to be largely impoverished, with a weak State presence that is almost completely irrelevant as a provider of public services. ${ }^{9}$ The economic disparities are further exacerbated by skilled workers who shun rural areas. This contributes to serious capacity constraints in rural areas. Hence, these different levels of capacity, and the financial disparities between urban and rural areas, are among some of the key factors which must be taken into account when designing a decentralisation programme. For instance, when assigning powers and functions to various forms of local government, as discussed in detail below, the capacity of local government units to perform such functions should be a key consideration. ${ }^{10}$ It is also important to have supervision measures specially tailored for the different levels of local government, given the differences among them.

Defining decentralisation within the African context also means that the role of traditional authorities and related practices is a key consideration. Traditional authorities are still relevant in a number of African countries where they form the immediate level of government. ${ }^{11}$ The institution is associated with certain drawbacks, namely: the irrevocable corruption of the institution due to its involvement with oppressive colonial administrations, undemocratic nature, and application of customary law, which is considered by some as oppressive, exploitative and discriminatory. ${ }^{12}$ Despite these drawbacks, the role of traditional authorities remains crucial, especially having regard to the support, respect and

\footnotetext{
9 Hatchard et al. (2004), p. 192.

${ }^{10}$ High category urban municipalities should be assigned more powers and functions since they are more likely to have the capacity to perform them more effectively. Conversely, municipalities in rural areas should be assigned fewer powers and functions given that they generally tend to have limited capacity to perform.

11 See Chigwata (2015), p. 444.

12 See Hatchard et al. (2004), p. 199.
} 
legitimacy they tend to command. ${ }^{13}$ Simply excluding traditional leadership in local government may come at a cost. In most parts of Africa, traditional leaders are vital to enhancing the legitimacy of rural local governments because they provide the link between the people and the government. Therefore, a decentralisation programme has to be designed paying particular attention to the local environment, taking into account issues, such as, the rural-urban divide and traditional practices, especially the place and role of traditional authorities.

The African Charter on Decentralisation recognises the importance of defining decentralisation within a context. Article 8(1) states that municipalities are to exercise their powers having regard to local realities, values, and customs, as well as national principles, norms and standards. The fact that local governments are mandated to exercise their authority with regard to local realities and values entails that the design of local government systems in respective African countries should consider factors, such as the rural-urban divide, as this is a local reality that cannot be ignored in most parts of Africa. The Charter also provides that historically marginalised groups and poor communities in both rural and urban areas should be included and given priority in public service delivery. ${ }^{14}$ Thus the Charter should be commended for requiring the consideration of disparities in the delivery of public services, among other things. Perhaps one of the biggest weaknesses of the Charter is its failure to expressly give recognition to the role of traditional leaders, given their role and relevance in a number of countries in Africa. There are several provisions of the Charter from which their role in local governance can nonetheless be inferred. This inference can be drawn from Article 8(2) which mandates local governments to implement projects or initiatives after having recognised the cultural, religious and gender diversity of the people within their respective territories. The fact that local authorities have to recognise cultural diversity can be inferred to mean that traditional leaders would need to be consulted in the decision making processes of the projects or initiatives, since traditional leaders are at the epicentre of culture practices most rural areas. The challenge is that traditional leaders are key governance structures in Africa whose role in local government should not have been ignored by the AU. ${ }^{15}$ The African Charter on Democracy of 2007 expressly recognised the role of traditional leaders. ${ }^{16}$ Given this recognition of traditional institutions in the earlier instrument, the express role of traditional authorities should not just have been recognised in the African Charter on Decentralisation, but developed further, in particular their relationship with modernday State structures.

\footnotetext{
13 See Chigwata (2015), p. 444.

14 Article 10(2) African Charter on Decentralisation.

15 See Chigwata (2015), p. 440.

16 See Article 27(9) and 35 African Charter on Democracy.
} 


\section{Security of Existence of Local Government Under African Charter on Decentralisation}

The security of existence of local governments is twofold. First, it pertains to the guarantee to exist, which the institution of local government has, whether as a sphere or tier of government. It is important to guarantee the existence of the institution of local government since local governments are unlikely to perform effectively if the existence of the institution is in constant jeopardy from higher authorities, which may abolish it at any time. For instance, the absence of security of existence deters local governments from having long-term developmental goals which are crucial for development. ${ }^{17}$ Constitutional recognition of local government provides the highest level of security for the existence of the institution of local government, given the cumbersome procedures involved to amend a Constitution compared to an Act of Parliament. This is partially the reason why the United Nations International Guidelines on Decentralisation and Strengthening of Local Authorities (UN Guidelines on Decentralisation) strongly recommends that the institution of local government be acknowledged in the Constitution. ${ }^{18}$

Article 5(1) of the Charter on Decentralisation provides that 'State parties shall enact domestic laws/regulations, recognising different levels of government'. Thus, the Charter provides some degree of protection for the institution of local government. Nevertheless, that protection is not the strongest safeguard of the institution of local government which is essential in ensuring that communities reap the benefits associated with decentralisation. For instance, in India before the passage of the 73rd and 74th Amendments of the Constitution that introduced the constitutional protection of local governments, states could dissolve local governments and take over their powers. ${ }^{19}$ Some countries on the African continent have gone beyond the mere recognition of local governments in domestic laws. The Constitutions of Namibia, Zimbabwe and South Africa recognise local governments as a separate sphere/tier of government. ${ }^{20}$ These Constitutions offer greater protection for the existence of the institution of local government than that afforded by the Charter. Therefore, the Charter does not provide for adequate protection for the existence of the institution of local government.

Secondly, security of existence also means that each local government unit should have a certain measure of protection. Local government units are also unlikely to perform effectively if they are in danger of being amalgamated and abolished or if their boundaries can be altered arbitrarily. ${ }^{21}$ Thus, certain mechanisms to reduce this arbitrariness become important. International best practices suggest that the procedures to be followed when establishing or abolishing a local unit, or altering its boundaries, should be clearly provided for in

\footnotetext{
17 Saunders (2005), p. 57.

18 Article C1 (1) United Nations International Guidelines on Decentralisation.

19 World Bank (1999), p. 110.

20 See Chapter 12, Constitution of the Republic of Namibia; Chapter 14, Constitution of Zimbabwe; and Chapter 7, Constitution of the Republic of South Africa.

21 Saunders (2005), p. 58.
} 
legislation. ${ }^{22}$ These procedures should be complied with in practice. The role of independent bodies in the establishment or abolition of local units or demarcating their boundaries is strongly encouraged to reduce the possibility of these governance processes being entirely a political process. The participation of concerned local authorities and communities is also paramount to allow them to influence these governance processes which have direct or indirect implications on their operations and lives, respectively. The African Charter on Decentralisation strives to provide a certain level of protection for the existence of each local unit.

Article 5(3) of the Charter on Decentralisation provides that 'geographical boundaries of areas falling within the jurisdiction of local governments...shall be modified in accordance with the provisions of the law'. Furthermore, Article 5(4) states that '...local authorities shall be consulted through clearly defined regulations on...legal instruments, sectoral policies, programmes, or projects that directly or indirectly affect their competencies'. Hence, the Charter affords a certain measure of protection to individual local government units since the modification of boundaries would be modified only in terms of the law. Furthermore, local authorities would be consulted when there is the establishment, disestablishment, demarcation of their boundaries and name changing of individual local governments, since such actions impact on their institutional and jurisdictional integrity. However, the protection afforded is inadequate because the Charter does not take into account procedural safeguards, such as, the consultations with and participation of communities and the role of an independent body in these governance processes. The South African constitutional and legislative provisions provide more significant safeguards for the existence of each municipality. South Africa has put in place regulations detailing the participatory role of communities and traditional authorities in the establishment, disestablishment, and name changing of local governments or the demarcation of their boundaries. ${ }^{23}$ Such governance processes are led or overseen by an independent body, the Municipal Demarcation Board. The involvement of all interested parties ensures that there is no erratic or arbitrary abolition of a municipality or re-definition of its boundaries, thus providing significant security for its existence. Therefore, the absence of provisions for mechanisms that protect the existence of individual local government units in the Charter leaves local government units vulnerable to being arbitrarily abolished or merged with other municipalities.

\footnotetext{
22 See for example, S 4(a) Municipal Demarcation (South Africa) Act 27 of 1998; Local Government (Scotland) Act 1973; S 55 Local Democracy, Economic Development and Construction (England) Act 2009; and Article 5 European Charter of Local Self-Government, 1985 (hereafter European Charter of Local Self-Government).

23 See Municipal Demarcation Act 27 of 1998.
} 


\section{Democratic Local Governance Under the African Charter on Decentralisation}

The basis of a developmental local government is democratic local governance where communities are substantially involved in local governance processes. Democratic local governance means that there are representative democracy, participatory democracy and measures to enhance all forms of accountability. The question is whether the African Charter on Decentralisation provides sufficient mechanisms to sustain representative, participatory and accountable local government.

\subsection{Democratically Elected Leaders}

A developmental system of local government is one in which local political leaders, such as councillors and mayors, are elected regularly and under an electoral system which guarantees free and fair elections. ${ }^{24}$ The direct election of these leaders by citizens in various communities is important to engender local accountability. ${ }^{25}$ The Charter upholds this notion of representative democracy. Article 5(2) requires local governments to be managed by democratically elected representatives. This is supported by Article 12(2) which upholds democracy as the foundation of local governance which should take place in a representative form. Article 8(3) also provides that the role of elected authorities be at the centre of the decision making process even after they have consulted non-elected parties, such as, cultural or religious groups. Article 13(1) requires that the elections of local public officials are to be enshrined in legislation clearly defining the modalities and timeframes of the elections. State Parties are also mandated to promote regular, democratic, free, fair and transparent local government elections. ${ }^{26}$ Therefore, from these provisions, it can be argued that the Charter sufficiently provides a foundation for democratic local governance on the African continent.

\subsection{Participatory Democracy}

The direct election of local leaders alone does not necessarily guarantee democratic local governance. Thus, there is a need for other mechanisms of promoting democracy at the local level, such providing citizens and their communities with opportunities to participate in local governance matters between elections. ${ }^{27}$ Such participatory democracy is important in a number of ways. For instance, participatory democracy strengthens relations between citizens and the State. It can also be an effective mechanism for checking on the use of administrative authority. Thus, participation through inclusiveness and the empowerment of citizens should be an underlying principle in decision making, implementation and

\footnotetext{
${ }^{24}$ Litvack and Seddon (1999), p. 97.

25 World Bank (1999), p. 121.

26 Article 13(2) African Charter on Decentralisation.

27 Litvack and Seddon (1999), p. 15.
} 
follow-up at the local level. ${ }^{28}$ Participatory democracy is on-going communication between local authorities and communities, as well as active involvement through associations, public consultation procedures, petitioning and complaints. ${ }^{29}$ In order to realise meaningful participation, communities should be provided with full, timely and easily accessible public disclosure of resource allocation decisions in budgets, procurements and expenditure programmes, among other areas. Participatory democracy is one of the fundamental characteristics of the African Charter on Decentralisation.

The Charter mandates local public officials to represent the interests of communities on an on-going and regular basis through clearly specified mechanisms and timeframes. ${ }^{30}$ Article $12(2)$ requires the communities' duty and right to participate to be guaranteed in national legislation. The Charter also extends community based participation to include the private sector and civil society. ${ }^{31}$ Article 12(5) requires local authorities to facilitate meaningful participation. The Charter does not go into the detail of how meaningful participation is to be facilitated but, as argued above, local governments should ensure that meaningful participation is about informed participation that influences results. Article 16(2)(b) seeks to promote the use of innovative and convenient ways of participation through the use of information and communication technology to encourage local residents and communities to provide feedback to their elected representatives. Article 12(6) encourages Africans in the diaspora, who tend to have financial resources and technical expertise, to participate in local development on the African continent given the financial and technical expertise they tend to command. Thus the Charter provides a solid foundation upon which participatory democracy can be built with potential to improve local governance on the continent.

\subsection{Accountability}

The degree to which local officials are accountable to their constituents determines whether decentralisation produces the intended benefits, that is, more efficient and responsive services. ${ }^{32}$ Accountability generally means being answerable for one's actions or lack thereof. Municipalities must justify their actions or lack thereof to their respective communities. Physical proximity of local government ideally makes it easier for citizens to hold local officials accountable for their performance. That is so because it is easier to go and demand services at local municipality offices that to go to the provincial or national offices that might be hundreds of kilometres away. The administrative establishment of local units should be accountable to elected local structures to ensure that local policies and objectives are enforced by local units. ${ }^{33}$ Mechanisms that further enhance accountability include regular elections,

\footnotetext{
28 Article A1(2) UN International Guidelines on Decentralisation.

29 De Visser (2005), p. 36.

30 Article 13(4) African Charter on Decentralisation.

31 Article 11(b) African Charter on Decentralisation.

32 World Bank (1999), p. 121.

33 Litvack and Seddon (1999), p. 39.
} 
audits, reporting requirements and performance assessments of local officials. The importance of accountability at the local level is recognised in the African Charter on Decentralisation. Article 11(f) provides that local authorities should be accountable to local communities when making and implementing local development decisions and policies as well as when they manage financial resources. Furthermore, Article 14(2) mandates local governments to publish and make accessible to communities, annual local government performance reports, and to disclose financial statements in full. The performance reports and financial statements enable communities to assess the conduct of public officials and hold them accountable. Therefore, it can be observed from the discussion above that the Charter provides a sufficient foundation for democratic local governance which will improve local governance.

\section{The Assignment of Powers and Functions to Local Government Under the African Charter on Decentralisation}

A decentralised system of government which upholds democratic local governance is likely to be ineffective if local governments are not equipped with certain powers and are not in charge of defined responsibilities. This argument entails that what local governments can achieve partially depends on the powers and functions they have. Thus, local governments should be equipped with a variety of powers, including the powers to make and implement laws and policies that have an impact on the wellbeing of the citizens. The question is: what nature and extent of powers should be assigned to local government in order to maximise the potential of decentralisation? Does the African Charter on Decentralisation guarantee such powers and functions?

\subsection{Assignment of Powers and Functions}

Municipalities should be assigned relevant significant powers and functions because without them they cannot be responsive to people's needs and the developmental potential of local governments is negated. ${ }^{34}$ The principle of subsidiarity is useful when allocating powers and functions to local government. The principle states that public responsibilities should be exercised by those elected authorities that are closest to the citizens. ${ }^{35}$ If the principle is followed, among other considerations, local government is likely to be allocated powers and functions which are relevant to a developmental mandate including: land use planning, primary health, sanitation, water and electricity. ${ }^{36}$ It is only when municipalities are afforded such relevant responsibilities that the notion of development driven at a local level can really take root. ${ }^{37}$ The assignment of such powers and responsibilities must not be

\footnotetext{
34 De Visser (2005), p. 37.

35 Article B 1(1) UN International Guidelines on Decentralisation.

36 Afonso and Fernandes (2008), p. 1948.

37 De Visser (2005), p. 33.
} 
ambiguous as that can result, among other things, in diminished accountability and resource wastage.

The African Charter on Decentralisation recognises the importance of assigning significant and relevant powers to local government. Article 6(1) states that 'central governments are to create enabling conditions for the decision-making .... and implementation to take place at lower levels of government where local authorities offer a better guarantee of pertinence and efficacy'. This provision reflects some elements of the principle of subsidiarity. It recognises that the assignment of powers and functions to local government should be informed by, among other factors, the need to improve efficiency in the delivery of public services. Article 5(1) provides that '[S]tate parties shall enact domestic laws/regulations, recognising different levels of government with the mandate to exercise their competencies'. While the Charter provides for the assignment of local government powers to exercise their mandates, it does not go further in detailing the nature of powers and functions that should be decentralised. The State parties have been given the discretion to determine what should be decentralised. The danger is that there is very little that prevents national governments from decentralising insignificant powers and functions that do not empower local authorities to undertake a key role in development. Accordingly, the Charter does not provide a solid platform for the assignment of relevant powers and functions to local government even though it provides useful direction.

\subsection{Administrative Authority}

A developmental system of local government is also one that affords local government authority over the human resources establishment as well as the administrative structures and procedures. ${ }^{38}$ Local government should be empowered to hire and fire administrative personnel in order to engender the accountability of local administrative officials to the local political structures, among other objectives. If these officials are appointed by higher officials, they are more inclined to further the interests of higher authorities at the expense of local priorities. ${ }^{39}$ Local governments should also be given a certain measure of discretion to determine their respective internal administrative structures and procedures so as to adapt these to local needs and to ensure effective management. ${ }^{40}$ The importance of administrative authority at local level is recognised by the African Charter on Decentralisation. Article 16(1)(a) requires the adoption of national legislation to 'empower local governments to determine and manage the organization of local public administration within a common national framework of standards, in order to ensure effective and enhanced delivery of quality and affordable services to local communities'. The Charter further states that 'local governments or local authorities shall identify and implement innovative service delivery modalities to local populations within a framework of national legislation' ${ }^{41}$ Therefore, the Charter

\footnotetext{
38 Litvack and Seddon (1999), p. 40.

39 World Bank (1999), p. 121.

40 Article D 1(2) UN International Guidelines on Decentralisation. See World Bank (1999), p. 120.

41 Article 16(1)(b) African Charter on Decentralisation.
} 
makes provision for the improvement of local governance on the continent through its provision of administrative powers to local government.

\subsection{Constitutional Protection of Powers and Functions}

Decentralised powers and functions are often re-centralised, especially by the national governments of a substantial number of African countries. The objectives of such re-centralisation differ across the continent but in the majority of cases recentralisation seems to be driven by political considerations. For instance, the recentralisation in 2006 of water and sanitation services in Zimbabwe is argued to have been driven by the need to leave the opposition dominated urban councils with less power and influence in urban areas. ${ }^{42}$ Such re-centralisation often cripples local government, especially when it involves functions that are pertinent to local revenue generation, such as water supply. It is against this background that some scholars have argued that it may be necessary to constitutionally recognise the powers and functions of local government. ${ }^{43}$ Such constitutional recognition secures local powers and functions as they cannot be re-centralised or modified without following the often cumbersome procedural requirements for constitutional amendments. Even though international literature is not conclusive on the constitutional protection of local government powers and functions, modern African Constitutions $^{44}$ have recognised local powers and functions to a varying degree. In these Constitutions the powers and functions of all spheres of government, and the basis upon which the powers and functions of local government may be modified, are explicitly recognised. This then provides significant safeguards for local powers and functions. The African Charter on Decentralisation provides a certain degree of protection for the decentralised powers and functions of local governments. Article 5(2) states that '...local authorities shall in accordance with national law, have the powers to' manage local affairs. Such legislative protection may be inadequate to safeguard local powers and functions given the simple procedures which often apply to legislative amendments. Therefore, the Charter does not adequately protect local government powers and functions from dangers such as re-centralisation.

\subsection{Final Decision Making Authority}

While the protection of local government powers and functions is vital, equally important is the need to equip local government with final decision making powers. What is the purpose of having a variety of responsibilities if local government lacks the necessary final decision making power over its competencies? It is difficult to imagine that local governments can be responsive to the particular needs and preferences of their respective communities without such powers. Hence, local governments should have final decision-making powers. Further, the powers of local government should not be undermined or limited by another sphere except as

\footnotetext{
42 Mushamba (2010), p. 109.

43 Hatchard et al. (2004), p. 197.

44 See for example, Constitution of Zambia, 2016; and Constitution of Kenya, 2010.
} 
provided for by law. Moreover, such limitation must not negate or stifle the developmental potential of local government. ${ }^{45}$ The objective as stated in the European Charter of Local Self-Government is to ensure that local government has full and exclusive powers. ${ }^{46}$ The question is whether the African Charter on Decentralisation requires the decentralisation of such powers. The Charter does not explicitly provide for such powers. Final decision making powers can, however, be deduced from Article 6(1) which, as stated above, requires decision-making and implementation to take place at the local government level. It is important that the decentralised powers are full and exclusive so that local authorities can make final decisions independent of the centre. Thus, the Charter has correctly recognised that a developmental design without final decision making powers is inadequate, as has been experienced in Zimbabwe. Despite municipalities in Zimbabwe having significant and relevant powers and functions, they have been unable to be responsive to the needs of local communities partially due to the fact that some of the policies and decisions they make on behalf of their communities are not approved by the central government which has final decision making powers on a variety of local functions. ${ }^{47}$ Thus, it can be noted from the discussion in this section of the Article that the Charter does not provide an adequate foundation for the assignment of powers and functions to local government which, therefore, limits its potential to improve local government on the continent.

\section{Revenue Generating and Expenditure Powers of Local Government}

The decentralisation of relevant and significant powers and functions is not enough for local governments to improve the wellbeing of local communities. Local governments require financial autonomy to execute those powers and functions without having to excessively depend financially on other spheres of government. ${ }^{48}$ Financial autonomy encompasses revenue mobilising measures, such as, taxes, intergovernmental transfers, borrowing and public-private partnerships. It also entails expenditure powers-the ability and discretion to spend generated revenue. This part of the article examines the Charter with the objective of establishing if it will improve local government in as far as revenue generation and expenditure of revenue are concerned.

\subsection{Revenue Generation Measures}

\subsubsection{Taxing Powers}

Local governments should be assigned taxing powers with significant revenue generation potential to ensure financial sustainability as well as to engender local

\footnotetext{
45 De Visser (2005), p. 94.

46 Article 4(5) European Charter of Local Self Government.

47 See Mushamba (2010), p. 107-110, 117-119.

48 Article D 2(7) UN International Guidelines on Decentralisation.
} 
accountability. Furthermore, municipalities should have the power to determine the tax rates so as to give them flexibility to adjust the tax rates in line with economic developments. Nevertheless, the national government should retain the power to set the framework within which the power to impose tax and determine tax rates can be exercised. Such regulatory powers are important to ensure that local fiscal autonomy does not adversely affect macro-economic stability and undermine equity, among other objectives. ${ }^{49}$ It is also important to ensure that 'local tax bases are real as revenue powers without tax bases are hollow powers' ${ }^{50}$ Thus, when demarcating municipal boundaries it is important to ensure that the size of local jurisdictions promotes financial viability of each local government. The African Charter on Decentralisation acknowledges the importance of taxing powers in generating revenue at the local level. Article 7(1) provides that "central governments should adopt legislation, measures and establish relevant mechanisms to give local governments the authority to mobilise and disburse resources at the local level for local economic development'. Furthermore, Article 7(5) requires local authorities to encourage and ensure that civil society, the private sector, communities, and national and sub-national entities pay local taxes. The Charter requires the administration of such taxes to be undertaken in a transparent and accountable manner with the central government exercising oversight. ${ }^{51}$ However, the Charter does not explicitly state the need to assign the power over tax rates to local government. Without the authority to set tax rates the potential of local governments to raise sufficient revenue is likely to be constrained. Furthermore, the Charter does not explicitly promote the need to establish viable local tax bases. The challenge presented by this is that local governments will not be able to raise sufficient revenue if they have the tax powers without viable tax bases.

\subsubsection{Intergovernmental Transfers}

Locally generated revenue should be complemented by intergovernmental grants to address vertical and horizontal fiscal imbalances which are common in any decentralised system of government. Intergovernmental grants to address vertical imbalances are transfers that fund services that local governments provide on behalf of the central government. ${ }^{52}$ Grants which address horizontal inequalities help to address the imbalances in fiscal capacity due to differences in the productiveness of tax bases in different local jurisdictions, among other reasons. The goal is also to ensure comparable levels of service provision across the country in line with equity objective. Litvack and Seddon note that an intergovernmental fiscal framework ought to be fair, equitable, transparent and participatory. ${ }^{53}$ To cater for those principles, some countries have established independent bodies to advise on the division of revenue between spheres so as to improve fairness, equitability,

\footnotetext{
49 World Bank (1999), p. 109.

50 De Visser (2005), p. 39.

51 Article 7(4) African Charter on Decentralisation.

52 World Bank (1999), p. 117.

53 Litvack and Seddon (1999), p. 31.
} 
transparency and participation. For example, the Financial and Fiscal Commission in South Africa is consulted, before the division of revenue, to make recommendations to government on the equitable division of revenue among spheres. ${ }^{54}$ Having the criteria for equitable sharing of revenue enumerated in the Constitution also improves the objectivity of the intergovernmental fiscal system. A predictable formula of sharing revenue, which is derived from the criteria, multilayer frameworks or projections of sharing revenue, also help to ensure predictability. ${ }^{55}$ The Constitutions of South Africa, Uganda and Zimbabwe have entrenched the criteria for equitable sharing among tiers of government to improve objectivity and predictability. ${ }^{56}$ Having platforms for local governments to participate in the determination of intergovernmental grants is one way of making an intergovernmental fiscal framework participatory.

The crucial role of intergovernmental grants has been recognised by the Charter. Article 7(2) provides that 'central governments are charged with creating the necessary oversight and evaluation mechanisms that ensure that the percentage of revenue collected at the national and local levels are effectively transferred to local governments for local economic development'. The Charter also upholds the principle of transparency and predictability as it states that both conditional and unconditional transfers from the central government to local governments ought to be transparent and predictable. ${ }^{57}$ Article 16(4)(c) states that 'central governments shall be responsible to equitably redistribute natural resource benefits acquired from natural resource exploitation in given localities and communities to all sub-national governments and local communities'. Thus, the Charter recognises the need for equitable redistribution of resources given the disparities that exist across Africa. Article 5(4) provides that local authorities should be consulted on policies that affect them. This can be interpreted to include the division of nationally raised revenue among the different spheres of government and between local governments which clearly affects the financial sustainability of local government. Therefore, the Charter provides a sound foundation for the use of intergovernmental grants to improve the financial state of local governments in Africa.

\subsubsection{Borrowing Powers}

Borrowing is another way to generate revenue which should be available to local governments. Loans are an important instrument for mobilising revenue especially when municipalities intend to spread the costs of investments over long periods of time. Borrowing powers encourage long-term investments in public infrastructure that are crucial to the realisation of developmental goals. ${ }^{58}$ However, only local governments with the capacity to repay loans should be allowed to borrow money

\footnotetext{
54 See, s 214(1) and (2) Constitution of the Republic of South Africa, 1996.

55 World Bank (1999), p. 110.

56 S 214(1) Constitution of the Republic of South Africa, 1996. Article 193 (4) Constitution of the Republic of Uganda. S 301 Constitution of Zimbabwe Amendment (No. 20), 2013.

57 Article 16(5)(e) African Charter Decentralisation.

58 Litvack and Seddon (1999), p. 32.
} 
subject to strict budget constraints, so that such local governments do not borrow excessively with the expectation that the central government would bail them out if they fail to repay the loans. The bailing out of local governments endangers fiscal policies designed to ensure macro-economic stability. ${ }^{59}$ Thus, there should be clear regulations stating that municipal loans are internal obligations of municipalities and not of the provincial and/or of the national government. The African Charter on Decentralisation recognises the need for local government to be allowed to borrow funds to finance development priorities. However, Article 16(5)(f) requires the regulation of such local government borrowing powers. The Charter leaves it to State Parties to determine the form of regulation, including the implementation of strict budget constraints. The Charter however stresses the importance of ensuring financial sustainability of local governments. ${ }^{60}$ Thus, the Charter provides the bedrock for the exercise of progressive borrowing powers that ensures that local government can generate revenue without negatively affecting the macro-economic stability of the respective African countries.

\subsubsection{Other Resource Raising Measures}

Besides the sources of revenue discussed above, municipalities should be allowed to generate revenue through other measures, such as Public-Private Partnerships (PPPs). PPPs are generally defined as long-term contracts between private parties and government entities to provide public services or assets. They can be effective ways of delivering value for money public infrastructure or services especially over long periods of time. However, legislation should regulate profit motives usually associated with private bodies as they could result in high prices, fees or charges relating to access to certain public services which may adversely affect equity goals. ${ }^{61}$ Article 7(3) of the African Charter on Decentralisation provides that central governments are to promote private sector and community development investments. Thus, the Charter should be commended for having recognised the need to allow local government to explore resource mobilisation measures other than the traditional sources of revenue, such as, taxes and grants. It will go a long way to promoting infrastructural development and other long-term investments by local governments in Africa.

\subsection{Expenditure Powers}

The ability of local government to adjust expenditure programmes to meet local needs and preferences significantly relies on the discretion local government has to utilise resources. Local expenditure powers, or budget autonomy, have an important bearing on the extent to which benefits associated with decentralisation can be realised. Hence, it is important to ensure that local government is assigned significant expenditure powers. Budget autonomy can be promoted in a number of

\footnotetext{
59 Article D 2(19) UN International Guidelines on Decentralisation.

60 Article 16(5)(c) and Article 10(5) African Charter on Decentralisation.

61 World Bank (1999), p. 108.
} 
ways. Not all intergovernmental grants should be earmarked as that leaves local government with no discretion to spend transferred grants. ${ }^{62}$ Revenue generated locally should ideally cover local expenditures as determined by local authorities, and not to finance priorities determined by higher levels of government. ${ }^{63}$ The African Charter on Decentralisation gives local governments significant expenditure powers. Article 16(5)(h) states that local authorities shall identify and establish mechanisms and processes for the efficient or optimal use of financial resources in the delivery of quality services. Furthermore, Article 16(5)(a) entrusts local governments with discretionary powers to manage financial resources at the local level. Therefore, the Charter guarantees sufficient expenditure powers, a development which is likely to improve local governance on the continent through increased discretion to spend revenue.

\section{Supervision of Local Government Under the African Charter on Decentralisation}

The design features discussed above emphasise the importance of local autonomy for a developmental system of local government. The unregulated exercise of such local autonomy, however, can lead to unintended consequences, such as, corruption and resource wastage. Moreover, the protection and promotion of certain national and local goals require that local autonomy be limited and checked by higher levels of government. ${ }^{64}$ Therefore, a balance should be struck between the need for local autonomy and the requirement for supervision. Central governments are also likely to afford greater autonomy to local government if they have the necessary mechanisms to correct problems that may arise at the local level. ${ }^{65}$ Supervision serves two purposes: it should be designed to ensure that local governments comply with the constitutional, legal and policy framework; and it should be performance focussed, with the objective to ensure that local governments achieve the performance targets set. ${ }^{66}$ It can generally be categorised into four forms; regulation, monitoring, support and intervention. The question is whether the Charter provides the necessary supervision measures and the relevant limitations thereof.

\subsection{Regulation}

The national government should retain the power to set the regulatory framework within which local governments exercise their powers and undertake their functions. For example, the central government should set regulatory frameworks for the establishment of governance structures and procedures, the minimum requirements

\footnotetext{
62 Article 9(7) European Charter on Local Self-Governance.

63 World Bank (1999), p. 117.

64 De Visser (2005), p. 226.

65 Litvack and Seddon (1999), p. 41.

66 De Visser (2005), p. 228.
} 
for key managerial positions, and national norms and standards relating to public service provision, for instance, water quality. These frameworks should however not go to the core of these functions because that would violate local autonomy which is vital if local government is to be developmental. ${ }^{67}$ They should also be predictable given that it would be difficult for local governments to comply with regulatory frameworks that are constantly changing. ${ }^{68}$ Financial regulation is particularly important in order to address vices, such as, corruption and resource wastage, as mentioned above. The need for higher levels of government to regulate the activities of local government is recognised in the African Charter on Decentralisation. Article 5(1) mandates Member States to enact regulations that clearly define the regulatory mechanisms that should guide local governments. However, the Charter fails to provide that the regulatory framework should not only be clear but also appropriate, that is, limited to frame-setting by not going to the core of local government powers and functions. If the Charter is implemented in its current form, there is nothing that prevents a national government on the continent from micromanaging local functions with only a limited knowledge of local conditions.

\subsection{Monitoring}

Monitoring pertains to the establishment of mechanisms to assess local government's performance and compliance within the regulatory frameworks discussed above. Higher levels of government should monitor municipalities by, for example, reviewing periodical reports on the set performance targets and undertaking periodical visits to local government. Fiscal monitoring mechanisms can be in the form of auditing financial books and systems of local government. It is however important that the monitoring mechanisms are not too intrusive. ${ }^{69}$ For instance, a requirement that the local government submit weekly performance reports to a higher level of government might result in local governments focussing more on compiling reports instead of delivering public services to communities. Thus, monitoring must be reasonable and respect local autonomy, as acknowledged by the African Charter on Decentralisation. Article 16(5)(b) provides that central governments shall ensure, through oversight, that allocated financial resources are managed effectively and efficiently without undermining the principle of local financial autonomy. Moreover, there is also central government oversight of locally generated revenue. ${ }^{70}$ The Charter also provides for monitoring mechanisms in respect of the publication of annual performance reports, as well as monitoring mechanisms to combat corruption and monitor different standards of ethical behaviour. $^{71}$ Therefore, the Charter provides a framework for the adequate

\footnotetext{
67 De Visser (2005), p. 94.

${ }^{68}$ De la Harpe et al. (2008), p. 3.

69 Harbich (2009), p. 63.

70 Article 7(4) African Charter on Decentralisation.

71 Article 14(2)(3)(6) African Charter on Decentralisation.
} 
assessment of the performance of local governments in relation to set standards, and in compliance with the regulatory frameworks.

\subsection{Support}

If the monitoring mechanisms, discussed above, reveal problems, then support should be offered to local government. Whereas support should be provided to all local governments it is particularly important to poorly-resourced local governments who usually lack the capacity to comply or/and perform. ${ }^{72}$ Support should be tailor made for each local government depending on the particular area in which the municipality needs to be supported. To protect local autonomy, it is important that the support be given in a manner that reinforces the decision making capabilities of local governments. ${ }^{73}$ Support can be in the form of capacity building as well as the deployment of staff and resources. The intergovernmental grants, discussed above, also act as financial support for local governments. Support with respect to financial management is also crucial in improving the capacity of local units to manage and report on the expenditure of its financial resources. The African Charter on Decentralisation is progressive in providing a framework for higher levels of government to render support to local governments. Article 16(3) provides that municipalities should be supported through capacity development workshops which ensure that local governments periodically get training which is essential to build their capacity for effective discharge of their respective mandates. The Charter also provides for the need for technological, software and administrative support to local government. Article 16(2) states that 'local governments shall be provided with the required human resources and Information and Communication Technology (ICT) to effectively and efficiently discharge their responsibilities'. The Charter stipulates that local governments should also receive financial support through intergovernmental grants, discussed above. Thus, there is no doubt that the implementation of provisions of the Charter that deal with support to local government will improve the state of African local governments.

\subsection{Intervention}

If the monitoring and support mechanisms suggest persistent problems at the local level that threaten the attainment of national and/or local goals, it may be necessary for higher levels of government to intervene at the local level. Intervention is the most extreme form of supervision. Accordingly, intervention powers must be limited, the grounds for intervention must be explicitly provided for in law, and there is need for oversight on the use of intervention powers. ${ }^{74}$ Intervention powers ought to be regulated in such a manner that local autonomy is protected, as intervention can be abused to advance political objectives. ${ }^{75}$ The African Charter on

\footnotetext{
72 World Bank (1999), pp. 117-120.

73 Harbich (2009), p. 55.

74 Article B 2(10) C 3(10) UN International Guidelines on Decentralisation.

75 De Visser (2005), p. 111.
} 
Decentralisation does not explicitly regulate the use of intervention powers by higher levels of government on the continent. This is detrimental as interventions can undermine local autonomy unjustifiably and expose local governments to politically motivated interventions that weaken democratic local governance. Opportunities for arbitrary interventions are also unlimited given that the grounds for interventions are not explicitly restricted. The Charter also does not provide for oversight mechanisms on the use of such intervention powers despite the fact that if such mechanisms are well designed they can provide safeguards for local autonomy. Without oversight mechanisms, local governments are deprived of judicial review to which they can resort if they are of the opinion that a particular intervention is unlawful. Thus, while the Charter's provisions for regulatory mechanisms are lukewarm, the Charter is silent on the regulation and limitation of intervention powers with regard to oversight and protection of local autonomy. Nevertheless, the Charter has a sound decentralisation framework in respect of monitoring and support mechanisms.

\section{Intergovernmental Co-operation Under the African Charter on Decentralisation}

While autonomy and supervision are regarded as cardinal principles that should be infused into a system of decentralisation, De Visser notes that intergovernmental cooperation should be the third principle that strengthens the decentralisation framework. ${ }^{76}$ Intergovernmental co-operation is important because the assignment of powers, under a decentralised system of government, is unlikely to provide exclusive compartments of powers and functions for each tier of government. There will be overlaps in the assignment of powers and functions among governments. As such, different spheres of government should be able to co-operate with each other and address challenges, such as, resource wastage and lack of accountability, that come with overlapping of powers. There are also instances where the different spheres of government need to deliver as one government; thus there is a need for intergovernmental co-operation. Mechanisms, such as, consultations, and joint planning and joint implementation of programmes and policies, can be effective in promoting co-operation and reducing disputes among governments. ${ }^{77}$ Local government associations play a crucial role in presenting a unified voice of local government when engaging other spheres concerning matters that affect local government. The realisation of certain development goals requires strategies that go beyond municipal boundaries. ${ }^{78}$ For that reason, the intergovernmental relations framework should facilitate horizontal co-operation and the formation of partnerships among municipalities to stimulate co-operation and remove hurdles to the integration of policies. $^{79}$

\footnotetext{
76 De Visser (2005), p. 173.

77 Fuglister (2012), pp. 317, 349.

78 Fuglister (2012), p. 321.

79 De Visser (2005), p. 175.
} 
The African Charter on Decentralisation provides a framework for intergovernmental co-operation that strives to create a viable and effective local government system on the continent. The Charter requires Member countries of the AU to create legal and institutional environments in their respective countries that encourage cooperation between different levels of government. ${ }^{80}$ Article 5(4) requires consultation with local government on national or sub-national legal instruments, sectoral policies, programmes, or projects that directly or indirectly affect their competencies. The consultation is not one-way since local authorities should also involve all relevant spheres in the development and implementation of local development plans and programmes. ${ }^{81}$ The need for horizontal co-operation among local governments is also recognised in the Charter through the provision of a legislative policy and institutional framework that is conducive to inter-municipal cooperation. Article 17(3) provides that national legislation should recognize the right of municipalities to form a national association. Article 17(7) requires central governments to encourage and support these local government associations in carrying out their mandate of being the voice and representative of local government. Therefore, the intergovernmental relations framework provided should be effective with the potential to improve the state of local government once implemented.

\section{Conclusion}

Over the years, the AU has adopted a number of Charters to address problems being experienced on the African continent. For instance, the African Charter on Decentralisation was adopted to help curb problems, such as, poor service delivery, underdevelopment and poor representation of communities that usually come with centralised systems of government. The Charter seeks to act as a catalyst for decentralisation towards improving the livelihood of all the people on the African continent. ${ }^{82}$ The primary objective of this article was to assess the model for local government or the decentralisation framework provided by the Charter which requires democratic local governance and the assignment of relevant powers and functions to local government. The Charter further requires the decentralisation of resources raising powers to the local level and the transfer of intergovernmental grants to local governments. It should be commended for its solid provisions on administrative authority which seek to empower local governments to determine their personnel and administrative structures and procedures. The Charter also requires that there be supervision of local governments, as well as co-operation between the different spheres of government. All these requirements will undoubtedly improve local government on the continent. However, its main weakness is that the Charter does not sufficiently guarantee local autonomy. This is reflected by, among other ways, the inadequate protection of local powers and functions, and the non-regulation and limitation of supervisory powers. The Charter

\footnotetext{
80 Article 6(2), (3) and Article 11(d) African Charter on Decentralisation.

81 Article 11(b) African Charter on Decentralisation.

82 Preamble, African Charter on Decentralisation.
} 
also fails to explicitly recognise the role of traditional authorities despite their relevance in most parts of Africa. Thus, the impact of the Charter on local governance on the continent may be constrained by these weaknesses. Nevertheless, the AU should be commended for putting forward the African Charter on Decentralisation, the first instrument to require, among other goals, vertical distribution of power to fight centralisation on the continent, promote local development and democracy.

\section{References}

Afonso A, Fernandes S (2008) Assessing and explaining the relative efficiency of local government. J Socio Econ 37:1946-1979

African Charter for Popular Participation in Development and Transformation, Arusha, Tanzania, 1990

African Charter on Democracy, Elections and Governance, Adopted by the Eighth Ordinary Session of the Assembly, held in Addis Ababa, Ethiopia, January 2007

African Charter on the Values and Principles of Decentralisation, Local Governance and Local Development, Adopted by the Twenty-Third Ordinary Session of the Assembly, held in Malabo, Equatorial Guinea, June 2014

African Union (2018) List of countries which have signed, ratified/acceded to the African Charter on the values and principles of decentralisation, local governance and local development. https://au.int/ sites/default/files/treaties/7802-sl-african_charter_on_the_values_and_principles_of_ decentralisation_local_.pdf. Accessed 10 Feb 2018

Bratton M (2012) Citizen perceptions of local government responsiveness in Sub-Saharan Africa. World Dev 40:516-527

Chigwata T (2015) Decentralization in Africa and the resilience of traditional authorities: evaluating Zimbabwe's track record. Reg Fed Stud 25(5):439-453

De la Harpe S, Rijken C, Roos R (2008) Good governance. Potchefstroom Electron Law J 11(2):1-14

De Visser J (2005) Developmental local government: a case study of South Africa. Intersentia, Antwerp

European Charter on Local Self-Governance, Strasbourg, 15.X. 1985

Fuglister K (2012) Where does learning take place? The role of intergovernmental cooperation in policy diffusion. Eur J Polit Res 51:316-349

Harbich J (2009) State supervision of local government authorities. Uprava 4:53-71

Hatchard J, Ndulo M, Slinn P (2004) Comparative constitutionalism and good governance in the commonwealth. Cambridge City Press, New York

Litvack J, Seddon J (1999) Decentralization briefing notes. http://siteresources.worldbank.org/WBI/ Resources/wbi37142.pdf. Accessed 6 Apr 2016

Mushamba S (2010) The powers and functions of local government authorities. In: De Visser J, Steytler $\mathrm{N}$, Machingauta $\mathrm{N}$ (eds) Local government reform in Zimbabwe: a policy dialogue. Creda Communications, Cape Town, pp 101-138

Saunders C (2005) Constitutional recognition of local government in Australia. In: Steytler N (ed) The place and role of local government in federal systems. Konrad-Adenauer-Stiftung, Johannesburg, pp 47-64. http://openknowledge.worldbank.org/handle/10986/5982. Accessed 14 Nov 2016

United Nations Human Settlement Programme (2007) International guidelines on decentralisation and the strengthening of local authorities. UN-Habitat, Nairobi

World Bank (1999) World development report 1999/2000: entering the 21st century. Oxford University, New York 